\title{
Selected Water-Resources Activities of the U.S. Geological Survey in New England in 2017
}

The New England Water Science Center of the U.S. Geological Survey (USGS) is headquartered in Pembroke, New Hampshire, with offices in East Hartford, Connecticut; Augusta, Maine; Northborough, Massachusetts; and Montpelier, Vermont. The areas of expertise covered by the water science center's staff of 130 include aquatic biology, chemistry, geographic information systems, geology, hydrologic sciences and engineering, and water use.

The USGS New England Water Science Center conducts hydrologic monitoring programs and water-resources investigations in partnership with more than 100 cooperators, who provide financial and technical support. The center cooperates with a wide range of agencies and other entities, including:

- more than 40 municipalities;

- State departments of transportation;

- State departments of environmental protection, conservation, and services;

- Native American tribes;

- Federal agencies, including the U.S. Army Corps of Engineers, Federal Emergency Management Agency, National Park Service, Environmental Protection Agency, and National Aeronautics and Space Administration; and

- international agencies such as the International Joint Commission (United States and Canada).

The center was established in 2012 through the merger of the four separate water science centers in Connecticut, Maine, Massachusetts-Rhode Island, and New Hampshire-Vermont. The merger retains USGS operations and offices in these former locations, while fostering greater integration of our activities. The new structure also makes available a wider range of scientific capabilities to each of the States, to better meet cooperator needs. Finally, the merger minimizes duplication of effort and provides a common voice for our regional and Federal partners in New England.

\section{Selected Regional-Scale USGS Water-Resource Activities in New England}

- Monitor streamflow at more than 440 sites throughout New England for flood forecasting, water-quality protection, drought tracking, and other purposes.

- Monitor groundwater at nearly 300 observation wells for water-resources management and drought tracking.

- Establish more than 200 sites along the New England coastline to monitor storm surges from tropical storms and Nor'easters.

- Produce new flood hazard maps for the general public and emergency managers, using state-of-the-art topographic and hydrologic information.
- Evaluate how changes in New England and the Nation's waters reflect changes in climate and variations in watershed characteristics.

- Assess groundwater, surface-water, and stream habitat quality at State, regional and national scales.

- Quantify domestic, industrial, irrigation and other types of water use in New England.

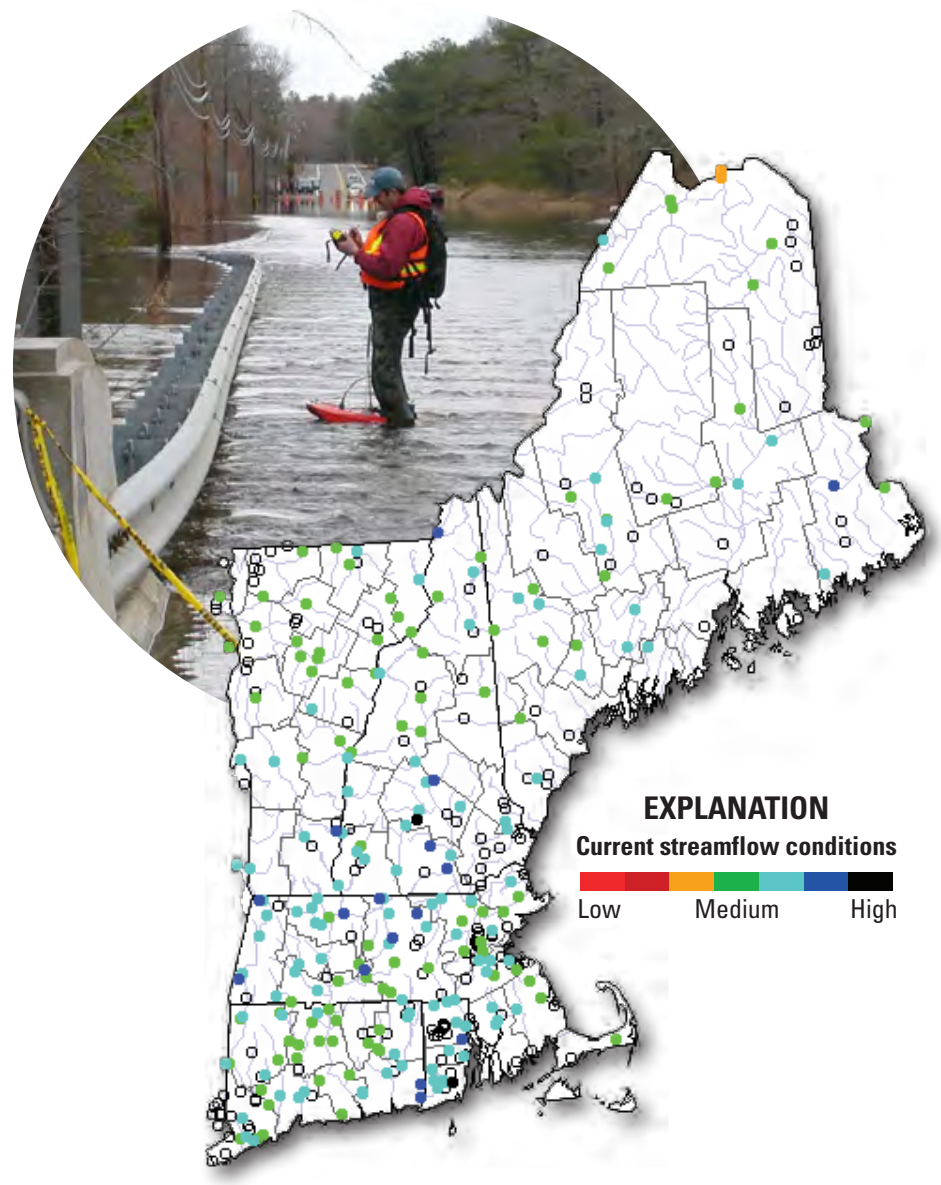

Figure 1. The U.S. Geological Survey operates a network of streamgages in New England, shown by circles on the map. The color of each circle indicates the streamflow for May 2017 at each streamgage, relative to the long-term median May streamflow at each streamgage. Circles with no color have less than 30 years of data. Photograph showing hydrographer measuring flood; by U.S. Geological Survey. 


\section{Selected State- and Local-Scale Water-Resources Activities in New England}

\section{Connecticut}

- Apply new USGS statistical methods to evaluate water-quality trends and long-term progress in reducing stream nitrogen loads to Long Island Sound (with the Connecticut Department of Energy and Environmental Protection).

- Develop an interactive, map-based tool to estimate daily time series of streamflows at any stream location, with and without the effects of water use (with the Connecticut Department of Energy and Environmental Protection).

- Assess the distribution and concentrations of arsenic and uranium in private bedrock wells in Connecticut in relation to water-quality standards for drinking water (with the Connecticut Department of Public Health).

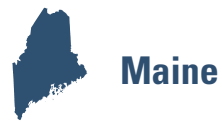

- Create a USGS StreamStats application for Maine, allowing users to estimate flood flows at any stream location in the State (with the Maine Department of Transportation).

- Model the effects of projected temperature and precipitation changes on the magnitude and timing of streamflows in the Meduxnekeag River watershed of northern Maine (with the Houlton Band of Maliseet Indians).

- Analyze effects of flood management alternatives in the Great Meadow wetland at Acadia National Park, an important historic and ecological landscape (with the National Park Service).

\section{Massachusetts}

- Evaluate changes in groundwater nitrogen concentrations resulting from nutrient reduction measures on Cape Cod (with the U.S. Environmental Protection Agency and the Cape Cod Commission).

- Assess, by using an automated station, loads of nutrients and metals transported daily in the Blackstone River from Massachusetts to Rhode Island (with the Massachusetts Department of Environmental Protection).

- Assess how impervious cover and other landscape factors affect biotic variability in streams in Massachusetts (with the Massachusetts Department of Environmental Protection).
Page 1 banner: Charles River dam, Natick, Massachusetts. Photograph by Mark V. Bonito, U.S. Geological Survey.

Page 2: Tuckerman Ravine, White Mountains, New Hampshire. Photograph by Sam Banas, U.S. Geological Survey.

\section{New Hampshire}

- Assess how projected climate changes will affect streamflows throughout the State (with the New Hampshire Departments of Health and Human Services and Environmental Services).

- Develop data and tools to predict when certain beaches may be closed due to excessive bacteria (with the New Hampshire Departments of Health and Human Services and Environmental Services).

- Determine areas along roadways where possible iron staining is likely to occur (with the New Hampshire Department of Transportation).

\section{Rhode Island}

- Characterize the flows and quality of streams entering the Scituate Reservoir, the primary drinking water source for more than 60 percent of the population of Rhode Island (with Providence Water).

- Define long-term trends in water quality in selected Rhode Island streams to better understand and quantify nitrogen loads to Narragansett Bay (with the Rhode Island Department of Environmental Management and the U.S. Environmental Protection Agency).

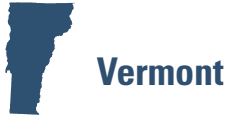

- Identify long-term changes in phosphorus loads entering Lake Champlain and its tributaries (with the Lake Champlain Basin Program).

- Research the effects of ski area development on the hydrology and water quality of mountain streams (with the Vermont Department of Parks, Forestry, and Recreation and the University of Vermont).

- Develop new flood forecasting tools for Lake Champlain and the Richelieu River in Canada (with the International Joint Commission and Canadian Government agencies).

\section{By Peter Weiskel}

\section{Contacts}

\section{U.S. Geological Survey}

New England Water Science Center and New Hampshire-Vermont office Keith Robinson, Director

Telephone: (603) 226-7807 (office) (603) 986-2327 (cell phone)

Email:kwrobins@usgs.gov

Website: https://newengland.water.usgs.gov/

Maine office
Robert Lent
Telephone: (207) 622-6602
Email: rmlent@usgs.gov

Connecticut office

Jon Morrison

Telephone: (860) 291-6761

Massachusetts-Rhode Island office

Matt Ely

Telephone: (508) 490-5040

Email: mely@usgs.gov 